\title{
Towards the Globalized Accounting Framework
}

\section{Syed Husain Ashraf*}

Department of Commerce, Aligarh Muslim University, Aligarh, India

The invention of the joint stock company in the seventeenth century was seminal event whose importance has often been understated. It made possible the collection of the savings of a large pool of individual savers and the channelization of these savings into vehicles for productive purposes. It thus made it possible for the fruits of the industrial revolution to be made available to industrial ventures and financed research and development and thus gave to society many of the benefits which we today take for granted but which have immeasurable improved the quality of our lives.

Company form of management is the legal form of innovation of capitalism- an artificial person with perpetual succession having rights and liabilities on its own name. It is most powerful institution of the nineteen century that has been transforming the global economy and quality of life of mankind. The principal of accounting converted into accounting standards are intended to create a framework in which the results of the business activities are faithfully and diligently communicated to the readers through financial statements. Such financial statements must create a confidence in the minds of its users and public at large that the financial strength reflected in these financial statements of the entity reflect the current position. The credibility of the financial statements prepared should be the hallmark of the work done by the accountancy profession.

Financial reporting has a role to play in ensuring that the management of companies discharges their responsibilities properly. Management must tell investors what resources the company acquired, why it is acquired them and how it used those resources. Management must tell what obligation the company incurred, why it incurred them and how it satisfied those obligations. Information of this kind is not only useful to buy, holds and sell decisions, it also helps investor decide how to vote on management's actions.

Globalization of economies has promoted cross border business entities. As a result, the complexity and uncertainty of doing business increased the enterprise risk manifold.

The emerging economic environment is the period of rapid change where industry would be in a state of white water, to thwart competition with new innovative business models, to meet an enhanced level of regulatory and legal compliance coupled with technological advances. The ability to rely on the figure shown in financial statements helps build confidence, the key ingredient in any successful market. The financial crisis only served to highlight how difficult it is to rebuild investor confidence when investors are uncertain about the information available to them. Investors flee uncertainty and run to quality during bad times. Therefore, it is clear that in today's highly interconnected global marketplace, the use of a single set of high quality International Financial Reporting Standards, offering transparency and comparability would be enormous benefit to investors.

Accounting Standards help in harmonizing various accounting policies and practices followed by businesses. Use of Accounting Standards reduces the alternatives in accounting treatments comparability of results over various periods for an organization as well as across the industry and provides meaningful information to various stakeholders in business and users of financial statements to empower them to make considered economic decisions.
Due to complexities of current businesses and introduction of e-commerce, new thinking in accounting concepts was imperative. Recognizing the needs of harmonizing accounting standards the world over, the International Accounting Standards Committee (IASC) was established in 1973 and it was reconstituted as the International Accounting Standards Board (IASB) which promulgated International Accounting Standards having worldwide acceptance.

In this era of globalization, it has become the need of the hour that companies across the globe and more particularly the listed companies should use a common set of accounting principles which would help investors to assess the performance of companies. Since IFRS has become the global language of financial reporting, International Accounting Standards Board or IASB, the standard setting body for IFRS has been in dialogue with the stakeholders around the globe and have been making amendments to existing Standards, introducing new Standards and also undertaking convergence project with the Financial Accounting Standard Board in the US, to develop accounting standards which can be universally accepted.

The accounting standards happen to be the grammar of accounting principles. Naturally, the accounting standards need to be reasonable stable in order to enable the preparers and users of the financial statements, to understand and implement them properly and diligently. In case there are constant changes in accounting standards, then the preparers as well as users take time before they comprehend the changes. Consequently, the implementation of the accounting standards may suffer over a period of time. When there are constant changes made in IFRS, it would be difficult for various countries to keep pace with the changing standards on a continuous basis. This would be true for those who have fully adopted IFRS and even for those who have converged them, since the converged standards will also need changes to keep pace with the changes in IFRS. The ever changing accounting standards can create an impression that the rules of measurement and the goal post itself are moving constantly.

IFRS has tried to bring about the uniformity in approach while dealing with the principles of accounting and has laid down the accounting standards which are expected to be followed globally. While the objective is laudable and desirable, it may have to be realized that the economic development within a country and the legal system, regulations and the practices prevailing in that country would adopt the IFRS in totality or converge these standards, keeping mind the legal system and economic environment in the country. Today business would wants and needs high quality accounting rules as well as a sound conceptual framework. It is not too far away when accounting standards are synchronized globally.

${ }^{*}$ Corresponding author: Syed Husain Ashraf, Department of Commerce, Aligarh Muslim University, Aligarh, India, Tel: 919412653056; E-mail: shusainashraf@ gmail.com

Received December 17, 2013; Accepted December 18, 2013; Published January 02, 2014

Citation: Ashraf H (2014) Towards the Globalized Accounting Framework. Int J Account Res 2: e101. doi: 10.4172/2472-114X.1000e101

Copyright: (C) 2014 Ashraf $\mathrm{H}$. This is an open-access article distributed under the terms of the Creative Commons Attribution License, which permits unrestricted use, distribution, and reproduction in any medium, provided the original author and source are credited. 